\title{
Nest initiation by multiple females in an aerial-nesting orchid bee, Euglossa cybelia (Apidae: Euglossini)
}

\author{
Diego Solano-Brenes, Mauricio Fernández Otárola, Paul E. Hanson \\ Escuela de Biología, Universidad de Costa Rica, San Pedro de Montes de Oca, San José 11501-2060, Costa Rica
}

Received 1 August 2017 - Revised 23 August 2018 - Accepted 6 September 2018

\begin{abstract}
Among orchid bees that have been observed, nest initiation by multiple females is rare, and has never been reported from an aerial-nesting species. Here, we document nest initiation by multiple females in the aerialnesting Euglossa cybelia. Observations were carried out on five nests, which were found on the undersides of understory palm leaves in Costa Rica. Female bees collaborated in constructing the envelope, but when this was finished each bee built and provisioned its own cells. This species therefore shows communal behavior. In one of the nests, individual foraging trips and interactions between female bees were quantified. Although, there were no overall differences between individuals with respect to initiating or receiving aggression, this changed over time.
\end{abstract}

aggressive interactions / communal behavior / nest construction / reproductive behavior

\section{INTRODUCTION}

Orchid bees (Apidae: Apinae: Euglossini) comprise nearly 250 described species and are restricted to the New World (Nemésio and Rasmussen 2011). They are best known for the males' behavior of visiting certain orchids and other sources of fragrances, which are stored in the enlarged hind tibiae and used during courtship (Dressler 1982; Cameron 2004; Roubik and Hanson 2004; Ramírez et al. 2011). On the other hand, nest architecture has been described in less than $20 \%$ of the species (Ramírez et al. 2002), and there are even fewer studies of female nesting behavior. Orchid bees rarely excavate their nests, but rather transport construction materials, especially plant resins, to the nesting site. Among

Electronic supplementary material The online version of this article (https://doi.org/10.1007/s13592-018-0605-z) contains supplementary material, which is available to authorized users.

Corresponding author: M. Fernández Otárola, mauricio.fernandez@ucr.ac.cr Manuscript editor: Alexandra Klein those species that have been studied, most nest in cavities, but some build exposed, aerial nests. The latter are known in a few species of Euglossa and have various forms: ball- or nut-shaped as in E. dodsoni Moure (Dodson 1966; Riveros et al. 2009); bowl-shaped as in E. hyacinthina Dressler (Eberhard 1988; Soucy et al. 2003; Capaldi et al. 2007; Wcislo et al. 2012) and E. turbinifex Dressler (Young 1986); dome-shaped as in E. championi Cheesman (Eberhard 1988), E. cybelia Moure (González et al. 2007), and E. dressleri Moure (Roubik and Hanson 2004); or irregular as in E. heterosticta Moure (Rasmussen et al. 2015). Most aerial nests are attached to the undersides of leaves, but those of E. dodsoni and E. hyacinthina are attached to stems.

All orchid bees utilize mass-provisioning to stock their cells with pollen and nectar. Usually, the nest is initiated by a single female (haplometrosis), but nest initiation by more than one female has been reported in the cavity-nesting E. annectans Dressler (Garofalo et al. 1998). The presence of more than one adult female in a nest most commonly results from daughters reusing 
their mother's nest, either with or without their mother. Among aerial-nesting species, multifemale nests have been reported in E. hyacinthina (Eberhard 1988; Soucy et al. 2003; Capaldi et al. 2007; Wcislo et al. 2012) and E. championi (Eberhard 1988). All females in these two species generally reproduce and therefore demonstrate a (facultative) communal social structure. In multifemale nests of some cavity-nesting species, one female (usually the oldest) exhibits aggressive behavior towards the other females and replaces their eggs with her own; moreover, the dominant female rarely leaves the nest whereas the subordinate females do most of the foraging and provisioning (Cocom Pech et al. 2008; Augusto and Garófalo 2009, 2011; Andrade-Silva and Nascimento 2012; Andrade et al. 2016). Such behavior suggests a degree of reproductive division of labor, suggesting that these species may be eusocial.

Here, we document the first known case of nest initiation by more than one female in an aerialnesting orchid bee, E. cybelia, a species that occurs from Costa Rica to Colombia (Roubik and Hanson 2004). We provide observations on nest building, interactions between females in the nest, and their relationship with ovary development of each female. As far as we are aware, the only previous publication on this species is that by González et al. (2007), who described a deserted nest in Colombia, and reared its unemerged bees and parasitoids.

\section{MATERIALS AND METHODS}

\subsection{Study site}

The study was carried out in the area around Quebrada Rancho on the edge of Piedras Blancas National Park, La Gamba, Golfito, Costa Rica $\left(8^{\circ}\right.$ $\left.40^{\prime} 20.4^{\prime \prime} \mathrm{N}-83^{\circ} 12^{\prime} 8.6^{\prime \prime}\right)$. The study area was in mature forest classified as very wet tropical forest (Bolaños et al. 2005). The average annual rainfall is $5836 \mathrm{~mm}$, with an average of 89 days without rain per year and with a dry season extending from December to April; the average annual temperature is $28.2^{\circ} \mathrm{C}$ and the average relative humidity is $88.3 \%$ (Weissenhofer and Huber 2008). The study was carried out in January 2015. The data were obtained from five nests of E. cybelia in various states of construction (Table I), located in an area of approximately $2500 \mathrm{~m}^{2}$, which was explored extensively in search of nests.

\subsection{Nest construction}

Observations of nest construction were made of two nests (Table I); nest A was observed for 25 days, beginning with the initial stages of construction, while nest $\mathrm{E}$ was observed for 2 days during an early stage of construction. The behavior of the resident females was recorded through direct observations on nest $\mathrm{A}$ and $\mathrm{E}$.

When the bees completed the construction of the envelope (nest covering), we made four openings in its surface by cutting it with a hot wire. After observing other nests where the envelope had naturally fallen away, with no apparent effects on bee behavior, we removed most of the envelope from the study nest and continued with the same method. Detaching the envelope altered the behavior of the bees only after 14:30, when they stopped foraging and began reconstructing the envelope (see results). We therefore ceased observations at 14:00 and each day, the detached envelope was then placed over the nest and secured with masking tape; it was removed again before 8:00 the following morning, a procedure that was followed for 5 days.

\subsection{Aggressive behavior and foraging}

These observations were carried out for 5 days on nest A, between 8:00 and 14:00 h. We removed the envelope (as described above) and recorded the behaviors with a Sony Handycam DCR-SR47 video camera, placed within 1 meter of the nest and white light was used to illuminate its interior. This process did not seem to affect the behavior of the bees. Each bee was marked with colored paper measuring $2 \times 2 \mathrm{~mm}$, which was glued to the scutellum with a minimum amount of "Super Bonder" glue (Figure 1a). The tags stayed in place during the entire period of observations, allowing us to identify individual bees (numbered from 1 to 7). With returning foragers we noted the following: the material with which each female entered the nest (pollen, resin, or no visible material on the 
Table I. Time (duration) of observation and behavioral observations recorded from aerial nests of Euglossa cybelia in different stages of construction.

\begin{tabular}{llll}
\hline Nest & Observation time (days) & Data collected & Construction status \\
\hline A & 25 & Social behavior, nest construction, natural history & Unfinished \\
B & 9 & Natural history & Finished \\
C & 8 & Natural history & Finished \\
D & 7 & Natural history & Finished \\
E & 2 & Nest construction & Unfinished \\
\hline
\end{tabular}

corbiculae), the duration of each foraging trip, and the time elapsed between consecutive trips.
Aggressive encounters between females, visits to another bee's cell, and thefts were quantified.
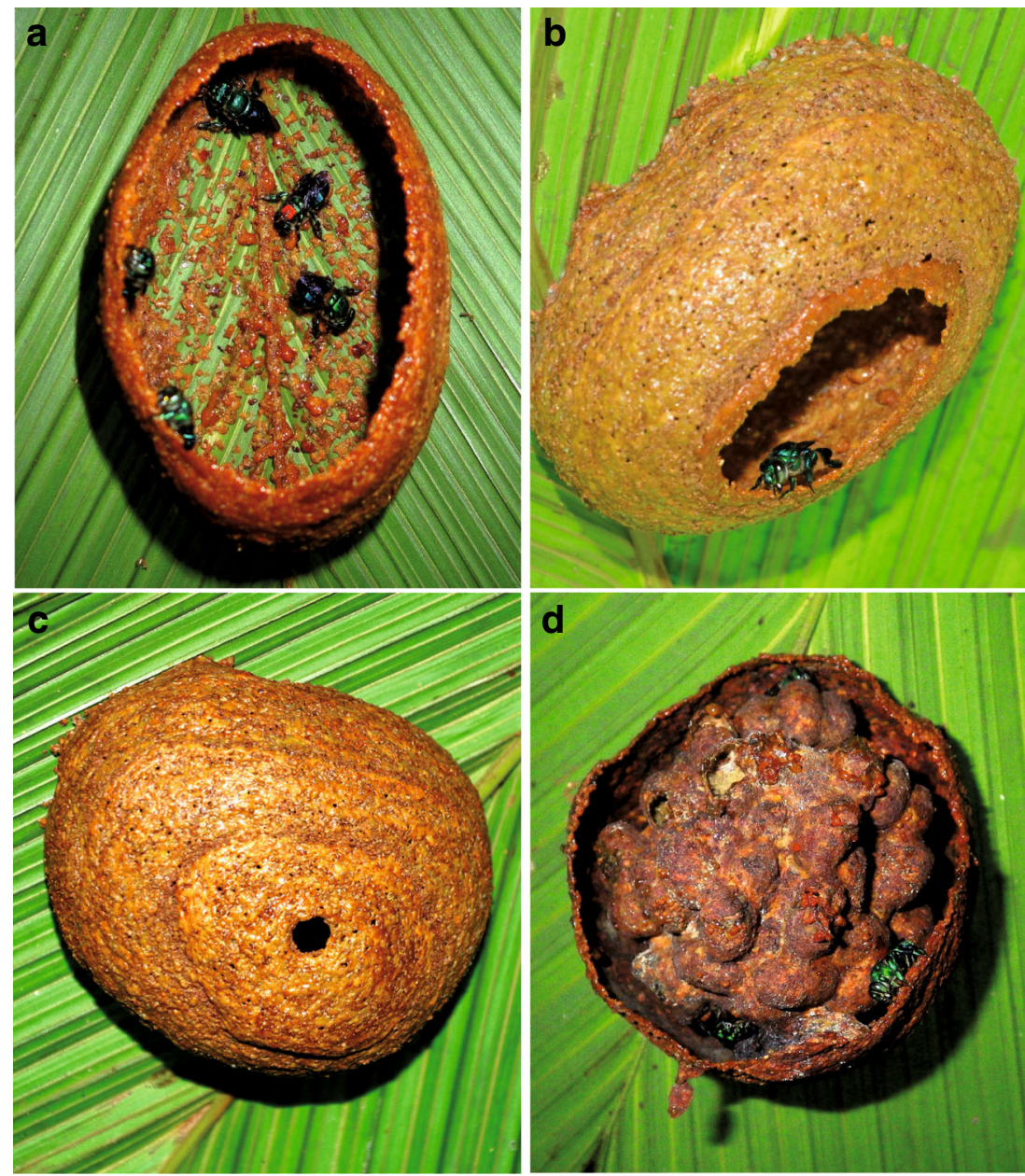

Fig. 1 Aerial nests of Euglossa cybelia in different stages of construction. a Initial stage of envelope construction, one bee shows a red tag on the scutellum; $\mathbf{b}$ envelope nearly complete, the fresh resin shows a darker color near the border, where the bee is working; c) envelope complete, the hole is the only entrance to the nest; $\mathbf{d}$ ) nest in an advanced stage of cell construction, the envelope was removed to show the mass of cells. 
The film recordings were carried out continuously, but for the analysis of the behaviors, the latter were fragmented into periods of $5 \mathrm{~min}$. Aggressive encounters were classified as attacks (when another bee's appendages were grasped with the mandibles) or fights (when another bee was held with the mandibles and pushed). In each case, we recorded which bee was the aggressor and which was the receiver of aggression, the proximity of the attack or fight to the cell of the aggressor (near its cell if the radius was within $1 \mathrm{~cm}$, or far from its cell if greater than $1 \mathrm{~cm}$ ), the condition of the cell (in construction, in process of being provisioned, or completed), and the number of bees in the nest at the time of the conflict.

A visit to another bee's cell was defined as entering (with at least a third of its body), or theft, when resin was removed from the other cell. In each case, we recorded the presence or absence of the cell's owner in the nest and the average number of females present during each observation period since there was considerable variation in the number of females between observation periods. The owner of the cell was defined as the bee that built and provisioned the cell.

Ovaries of six females from nest A were dissected and removed in order to determine their condition. To compare their morphology, we photographed the left ovary (ventral and lateral view) of each bee using a Leica EZ4HD stereo microscope.

\subsection{Data analysis}

To determine whether the aggression received differed among recipient bees, we used a generalized linear mixed models with PQL (penalized quasi-likelihood). The number of aggressive encounters was $\log 10$ transformed and the date was used as a random variable. For the analysis, a negative binomial distribution was assumed. To obtain paired comparisons between bees, we changed the bee in the model used to calculate the intercept, which allows us to observe the differences between this bee and all the others. We repeated this process to obtain all possible combinations.

To determine if the number of aggressive encounters initiated depends on the condition of the cell of the aggressor, a chi-square test was used. The "in construction" and "completed" conditions were grouped because of the small number of observations of these cases. Expected values were weighted by the number of observations in each category. The same method was used to determine if the number of initiated aggressive encounters varied according to the aggressor bee. A chi-square test was utilized to determine whether the aggressive encounters varied with respect to the distance from the cell of the aggressor bee.

Spearman's correlation was used to test the effect that the average number of females within the nest had on the number of visits and thefts to another bee's cell. We also used chi-square tests to determine if the number of visits and thefts to the cell of another bee were independent of the presence/absence of the owner of the cell. The data were obtained by repeated observations of the sex bees.

All analyses were done in R ( R Development Core Team 2008). The GLM's were performed with the package MASS (Venables and Ripley 2002) and the GLMM with nlme (Pinheiro et al. 2016).

\subsection{Identification of specimens}

Euglossa cybelia was identified with keys provided in Roubik and Hanson (2004). Voucher specimens are deposited in the Zoology Museum of the University of Costa Rica.

\section{RESULTS}

\subsection{Nest structure and construction}

The five nests were found on the undersides of leaves of understory palms (Asterogyne sp. $n=4$; Geonoma sp. $n=1$ ); the base of the nest had an approximate angle of $45^{\circ}$ with respect to horizontal and they were all less than $2.1 \mathrm{~m}$ from the ground. All nests were located less than $10 \mathrm{~m}$ from small streams with widths less than $4 \mathrm{~m}$ and a reduced flow during the time of sampling. The nests were elliptical at their base, measuring $41.12 \pm 9.18 \mathrm{~cm}^{2}$ (mean $\pm \mathrm{SD}$ ) in area, $6.86 \pm$ $1.10 \mathrm{~cm}$ in width, and $7.70 \pm 0.87 \mathrm{~cm}$ in length; the entrance to the dome-shaped envelope was 
$0.67 \pm 0.02 \mathrm{~cm}$ in diameter but varied in its position. The nests were built entirely of a light brown, sticky resin of unknown plant origin.

At the central point of the ellipse in nests $A$ and E, a set of cells was constructed and expanded laterally to occupy nearly the entire internal volume, leaving only a small space between the envelope and the outer cells. This planar group of cells is attached to the leaf by means of a single stalk. The number of cells in completed nests was $59 \pm 24$.

In the initial stages of construction, four to five females built a ring of resin that grew in height over time, with small accumulations of resin distributed inside the ring on the surface of the leaf (Figure 1a). On the second day, the envelope was close to completion (Figure 1b) and it was finished on the third day (Figure 1c). At this stage, the envelope was thin and porous, but it became harder and more resistant as nest construction progressed.

The construction of the cells began with an accumulation of resin approximately $2-\mathrm{cm}$ long in the center of the ring formed by the base of the envelope. This is the beginning of the stalk that holds the cells to the leaf. The accumulation of resin began before completion of the envelope, but the first cell was built only after the envelope was completed. In three of five nests, the peduncle was attached to the central vein of the leaf.

The construction and provisioning of each cell was carried out by a single female, and the resin used came from the accumulation on the leaf surface within the nest as well as resin obtained from other cells and additionally foraged outside the nest. The first cell of the nest A was constructed by excavating a hole in the stalk and by placing the extracted resin around the edges of the hole; the bee inserted its head into the hole and used its second and third pair of legs (which remained outside the hole) to press the resin into the cell walls that were being formed. The construction of a cell took less than $24 \mathrm{~h}$. Each bee built its own cells sequentially and in a group, which was in contact with groups of cells of neighboring bees.

The number of bees within the nest increased during the construction of cells up to a maximum of seven; the origin of the two new individuals is unknown, but it is clear that they did not participate in the construction of the envelope. The number of open cells equaled the number of females occupying the nest. After 21 days from the time of initiating nest construction, bee 1 left the nest. The number of cells built varied among bees. For 7 days only three of seven bees built new cells (one to two cells each). During the 26 days of observation, a total of 32 cells was built (28 sealed cells). In the other nests, 74, 72, and 31 cells were counted (Figure 1d). In the final stages of construction, when the mass of cells was close to occupying the entire space, some of the cells became joined to the envelope.

\subsection{Foraging}

The entrance to the nest was kept open between approximately 7:30 and 14:30. On average, the bees remained $37 \% \pm 20 \%$ of the time out of the nest. During the 5 days of observation, we documented 209 foraging trips of bees entering the nest; $41 \%$ of these had empty corbiculae, $33 \%$ carried resin, and $26 \%$ had pollen.

The material with which the bees entered the nest varied between individuals (Figure 2). The bees with open cells (bees 2, 4, and 6) carried more pollen than bees with closed cells (bees 1 , 3 , and 7). During the recorded time, bee 5 did not enter the nest with any material in spite of having an open cell. For most bees, the time spent in the nest was greater than the time spent foraging (Figure 3).

\subsection{Aggressive behavior}

We observed a total of 462 aggressive encounters during 5 days of observation. Only one of these was not related to protection of cells. Of these aggressive encounters, $84 \%$ were attacks and $16 \%$ were fights; $85 \%$ of the aggressive encounters occurred during provisioning. Aggressive encounters were more frequently initiated by bees 2,4 , and $6\left(\chi^{2}=234.55, \mathrm{df}=6, p<\right.$ 0.001 ; Fig. S1 in electronic supplementary material). Only bee number 5 received less aggression than bees 2 and 7 (Fig. S2 and Table S1 in electronic supplementary material). Bees that were provisioning their cell showed more aggression than bees with closed cells or cells under 


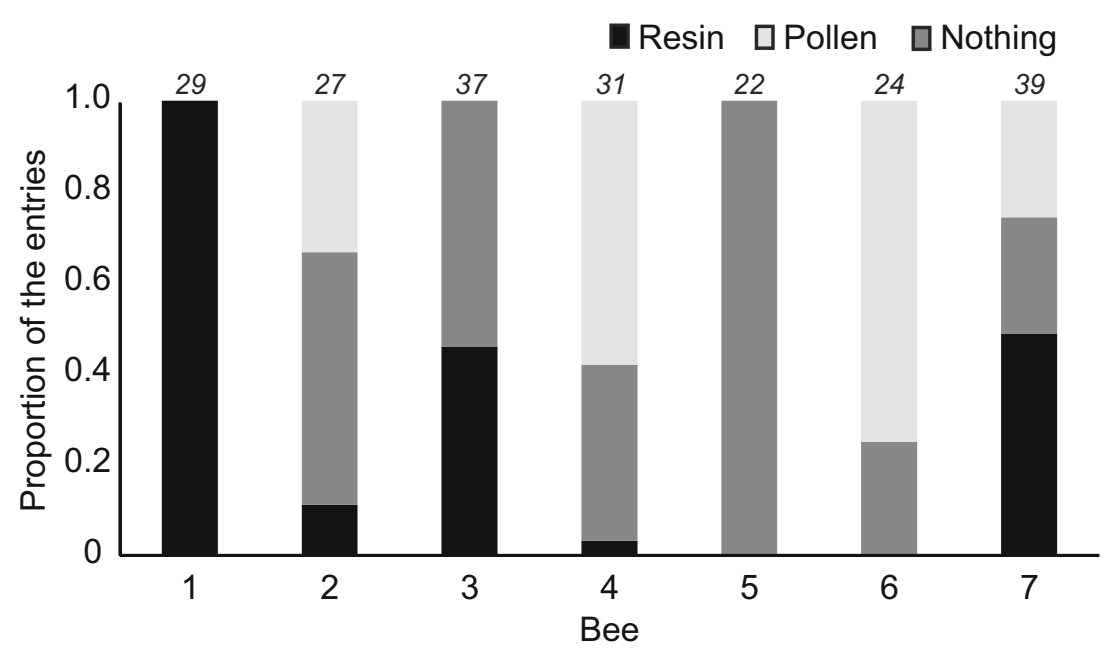

Fig. 2 Nest entries according to resources observed on the corbiculae of E. cybelia. The values above each bar indicate the total number of nest entries during the 5-day observation period.

construction $\left(\chi^{2}=77.21, \mathrm{df}=1, p<0.001\right)$, and $74 \%$ of the aggressive behaviors occurred close to the cell of the aggressor bee $\left(\chi^{2}=94.35, \mathrm{df}=1\right.$, $p<0.001)$. Conflicts that occurred farther from the cell of the aggressor were mostly due to an attempted theft from another bee's cell. In one case, rather than attempt to remove resin or provisions, the female took possession of another bee's cell and proceeded to defend it against other bees.

During 5 days of observations, we recorded a total of 901 visits to neighboring cells and 112 cases of theft. In $98.4 \%$ of the visits to neighboring cells, the bee inserted its head into the cell, and in $1.6 \%$ of the cases (involving three individuals), the bee inserted its abdomen. Inserting the head or abdomen occurred quite rapidly (usually less than

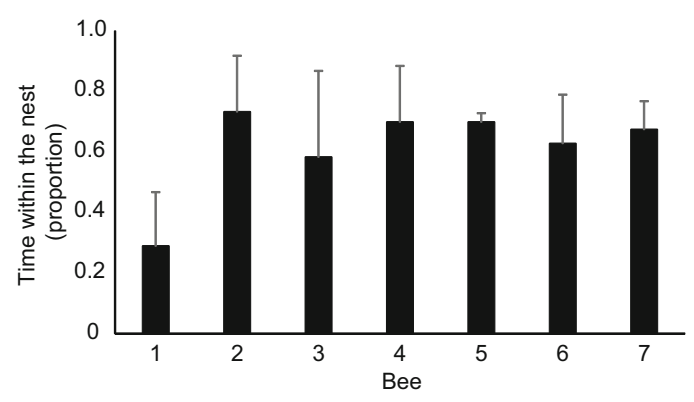

Fig. 3 Daily average proportion of time inside the nest of Euglossa cybelia .
$5 \mathrm{~s})$ and whether the former involved removing provisions could not be determined; oviposition probably did not occur since this requires several minutes (Cocom Pech et al. 2008). Only two (bees 1 and 5) of the seven bees did not visit neighboring cells. Most visits to neighboring cells (63\%) and most thefts $(82 \%)$ occurred in the absence of the cell's owner within the nest $\left(\chi^{2}=63.86, \mathrm{df}=\right.$ $1, p<0.001$, and $\chi^{2}=32.14$, df $=1, p<0.001$, respectively). The number of females within the nest showed a slight negative correlation with the rate of visits to neighboring cells ( $\rho=-0.13, p=$ $0.007)$ and with the number of thefts $(\rho=-0.21$, $p=0.016$ ).

Bee 5 disappeared from the nest on day 4, and on day 5 , it was observed in another nest participating in nest construction and foraging for resin. The only aggression observed during construction of the envelope was against this bee in its second nest. Visits by bees to other nests to steal resin were quite frequent, but were not quantified. Visits by bees from other nests sometimes provoked defensive behavior by the resident bees, but on other occasions the foreign bee was ignored.

In four of the six bees, an enlarged ovariole was observed in each ovary (each ovary has four ovarioles). The morphology and size of the ovaries, as well as the development of the ovarioles, varied between bees. However, bee 5 was the only one that had very small ovaries and completely lacked 
mature eggs. On the first day of the behavioral observations, this bee attempted to close its cell but reopened it, and never built another one. Another bee visited bee 5's cell and inserted its abdomen into this cell, even though bee 5 was in the nest.

\section{DISCUSSION}

\subsection{Nest construction}

To the best of our knowledge, this is the first description of nest construction in E. cybelia and the first report of cooperation between multiple individuals in a Euglossa species with an aerial nest. The participation of two females has been reported in the founding of a nest in pre-existing cavities in E. annectans (Garofalo et al. 1998). The latter species also differs in that aggregations of cells of different females are separated (> $1 \mathrm{~cm}$ ), while in E. cybelia, they are in contact.

Species that build nests in cavities invest less energy in the collection of structural materials since the latter are only used in the construction of cells and the nest entrance (Garofalo et al. 1998; Augusto and Garófalo 2004). This reduces the potential benefits of cooperation between females, since it is easier for a single female to build the nest. Building an envelope to cover cells on an exposed surface might require more effort than finding and defending a cavity, depending on the relative availability of cavities versus resin sources. In E. hyacinthina, a single female builds the envelope in approximately 6 days (Wcislo et al. 2012). In contrast, the construction of a similar-sized envelope in E. cybelia required only 3 days (although this time probably varies according to the number of participating females). The decrease in construction time could be an advantage of cooperation between females in E. cybelia, especially in seasonal environments or those with a marked variation in the phenology of resources.

The increase in the number of females within the nest demonstrates the incorporation of females from outside the initial group. This process has also been reported in E. nigropilosa Moure (Otero et al. 2008). The incorporation of additional females during the early stages of nest construction and occasional nest switching suggest that nest founding in E. cybelia may not be dependent on daughters remaining in their maternal nest (although this cannot be ruled out after the daughters emerge in more advanced stages). In E. townsendi Cockerell, E. fimbriata Rebêlo \& Moure, and E. carolina Nemésio the incorporation of new bees into the nest is common, but these are daughters of the founder, which remain in the nest and build cells (Augusto and Garófalo 2004, 2009, 2011). Non-related individuals have been shown to usurp nests of conspecifics in E. melanotricha Moure (Andrade-Silva and Nascimento 2015) and E. cordata (L.) (Freiria et al. 2017).

Some bees disappeared from the nest. Prior to their disappearance, these individuals were observed to lack active cells, although they were involved in nest repair and foraging for resin. Presumably, these bees were either victims of predation while foraging or they joined another nest; the latter could be a response to the small number of cells they built in the original nest, which could in turn be a result of being frequent recipients of aggression. Disappearance of bees from the nest has also been reported in E. carolina and E. melanotricha (Augusto and Garófalo 2011; Andrade-Silva and Nascimento 2012).

\subsection{Foraging}

Pollen was the resource most frequently observed on the corbiculae of bees returning to the nest. Once a cell has been constructed, there is probably an increased demand for pollen, so that the cell can be provisioned as quickly as possible, an egg laid, and the cell closed. This would benefit the bee since it minimizes theft and allows it to build more cells. Not surprisingly, bees that were in the process of constructing and provisioning cells (i.e. foraging) spent less time in the nest. At least some of the bees returning to the nest with empty corbiculae had probably been foraging for nectar, which is used as food by both the adult bee and the larva.

In the present study, the bees that received most aggression by nestmates left the nest more frequently and only collected resin. Greater foraging activity by subordinate bees has also been observed in other species, for example in 
E. viridissima Friese, although in that case, one subordinate acted as a forager and the other as a guard bee to protect against resin theft (Boff et al. 2015). In E. nigropilosa, bees entering with resin neglected their brood cells and the provisioning of their cells (Otero et al. 2008).

\subsection{Aggressive behavior}

Euglossa cybelia appears to exhibit communal behavior, since several females of the same generation live together in the nest, but each builds, provisions, and oviposits in its own cells (Michener 1969). This type of sociality appears to be relatively common among Euglossa species and has been reported in E. townsendi (Augusto and Garófalo 2004), E. carolina (Augusto and Garófalo 2011), E. championi and E. hyacinthina (Eberhard 1988), E. aeneus (Garofalo et al. 1998), E. nigropilosa (Otero et al. 2008), and E. erythrochlora Moure (Dressler 1982). Like E. nigropilosa, each individual of E. cybelia defended its own brood cells (Otero et al. 2008). Aggression by temporarily appropriating another bee's cell suggests attempts of theft, a behavior also reported in E. carolina (Augusto and Garófalo 2011). In both E. cybelia and E. nigropilosa, a bee is attacked when it is in proximity of another bee's cell (Otero et al. 2008), for example while performing nest repairs.

Aggression during the provisioning period is due to theft of resin or visits to other cells. In E. cybelia, there was clear variability of aggressive behavior between individuals, with some bees behaving as subordinates and permitting possible ovipositions in their cells, as has been observed in E. carolina and E. townsendi (Augusto and Garófalo 2004, 2011). In E. carolina dominant bees use high levels of aggression to usurp cells (Augusto and Garófalo 2011). In E. carolina, E. melanotricha, E. fimbriata, E. townsendi and $E$. annectans dominance has been observed to alternate between individuals over time (Andrade-Silva and Nascimento 2012; Augusto and Garófalo 2004, 2009, 2011; Boff et al. 2017). The same was observed in E. cybelia, although it is not clear whether this represents incipient division of labor or that subordinate individuals were weaker (due to disease or age). Our observation that ovariole development varied between bees (with one individual completely lacking mature eggs) is also suggestive of incipient division of labor, although this variation can also depend on when the last egg was laid. The contents of the spermatheca, another measure of reproductive potential, were not examined.

The dominant female in a number of Euglossa species consumes the eggs of subordinates and oviposits in their cells (Augusto and Garófalo 2004, 2007, 2009, 2011; Cocom Pech et al. 2008; Freiria et al. 2017). In the majority (98.4\%) of visits to another's cells in E. cybelia, no oviposition occurred, but rather the intruder inserted its head into the cell which possibly represents searching for resources (pollen/nectar) within the cell. As with the theft of resin, obtaining food within the nest means less foraging, allowing a dominant bee to better protect its own cells and reduce energy expenditure involved in foraging. The theft of resin inside the nest and even the theft of resin from other nests may hint at a limitation of this resource in the environment. In a study of E. nigropilosa, it was suggested that resin was one of the limiting resources, and this could be one of the factors influencing the construction of communal nests (Otero et al. 2008).

\section{ACKNOWLEDGMENTS}

We thank William Eberhard, Daniel Arauz, and José Zelaya for the help in locating nests; William Eberhard and Mary Jane West-Eberhard for guidance in the collection of data and discussion of results; Gilbert Barrantes for his help with the data analysis; and four anonymous reviewers for helpful suggestions for improving the manuscript. This work is the result of the Field Biology Course organized by the School of Biology of the University of Costa Rica.

\section{AUTHORS' CONTRIBUTIONS}

DSB and MFO conceived this study; DSB collected and analyzed the data; DSB, PH, and MFO wrote the paper and participated in the revision of it. All authors read and approved the final manuscript. 


\section{COMPLIANCE WITH ETHICAL STANDARDS}

Conflict of interest The authors declare that they have no conflict of interest.

Initiation du nid par plusieurs femelles chez une abeille à orchidées nidifiant dans des nids aériens, Euglossa cybelia (Apidae: Euglossini)

Interactions agressives / comportement communautaire / construction du nid / comportement reproductif

\section{Nistbeginn von multiplen Weibchen der frei-nistenden Prachtbiene Euglossa cybelia (Apidae: Euglossini)}

Aggressive Interaktionen / kommunales Verhalten / Nestbau / Reproduktionsverhalten

\section{REFERENCES}

Andrade, A.C.R., Miranda, E.A., Del Lama, M.A., Nascimento, F.S. (2016) Reproductive concessions between related and unrelated members promote eusociality in bees. Sci. Rep. 6, 26635

Andrade-Silva, A. C. R., Nascimento, F. S. (2012) Multifemale nests and social behavior in Euglossa melanotricha (Hymenoptera, Apidae, Euglossini). J. Hymenopt. Res. 26, 1-16.

Andrade-Silva, A. C. R., Nascimento, F.S . (2015) Reproductive regulation in an orchid bee: social context, fertility and chemical signalling. Anim. Behav. 106, 43-49.

Augusto, S. C., Garófalo, C. A. (2004) Nesting biology and social structure of Euglossa (Euglossa) townsendi Cockerell (Hymenoptera, Apidae, Euglossini). Insect. Soc. 51, 400-409.

Augusto, S. C., Garófalo, C. A. (2007) Nidificação de Euglossa (Euglossa) melanotricha Moure (Hymenoptera: Apidae) no solo do Cerrado. Neotrop. Entomol. 36, 153-156.

Augusto, S. C., Garófalo, C. A. (2009) Bionomics and sociological aspects of Euglossa fimbriata (Apidae, Euglossini). Genet. Mol. Res. 8, 525-538.

Augusto, S. C., Garófalo, C. A. (2011) Task allocation and interactions among females in Euglossa carolina nests (Hymenoptera, Apidae, Euglossini). Apidologie. 42, $162-173$.

Boff, S., Forfert, N., Paxton, R. J., Montejo, E., QuezadaEuan, J. J. G. (2015) A behavioral guard caste in a primitively eusocial orchid bee, Euglossa viridissima, helps defend the nest against resin theft by conspecifics. Insect. Soc. 62, 247-249.
Boff, S., Saito, C. A., Santos, I. A. (2017) Mutlitple aggressions among nestmates lead to weak dominance hampering primitively eusocial behaviour in an orchid bee. Sociobiol. 64, 202-211.

Bolaños, R., Watson, V., Tosi, J. (2005) Mapa ecológico de Costa Rica (Zonas de Vida), según el sistema de clasificación de zonas de vida del mundo de L.R. Holdridge, Escala 1:400 000. Centro Científico Tropical, San José, Costa Rica.

Cameron, S. A. (2004) Phylogeny and biology of Neotropical orchid bees (Euglossini). Annu. Rev. Entomol. 49, 377-404.

Capaldi, E. A., Flynn, C. J., Wcislo, W. T. (2007) Sex ratio and nest observations of Euglossa hyacinthina (Hymenoptera: Apidae: Euglossini). J. Kansas Entomol. Soc. 80, 395-399.

Cocom Pech, M. E., May-Itzá, W. J., Medina Medina, L. A., Quezada-Euán, J. J. G. (2008) Sociality in Euglossa (Euglossa) viridissima Friese (Hymenoptera, Apidae, Euglossini). Insect. Soc. 55, 428-433.

Dodson, C. H. (1966) Ethology of some bees of the tribe Euglossini. J. Kansas Entomol. Soc. 39, 607-629.

Dressler, R. L. (1982) Biology of the orchid bees (Euglossini). Annu. Rev. Ecol. Syst. 13, 373-394.

Eberhard, W. G. (1988) Group nesting in two species of Euglossa bees (Hymenoptera : Apidae). J. Kansas Entomol. Soc. 61, 406-411.

Freiria, G. A., Garófalo, C. A., Del Lama, M. A. (2017) The primitively social behavior of Euglossa cordata (Hymenoptera, Apidae, Euglossini): a view from the perspective of kin selection theory and models of reproductive skew. Apidologie 48, 523-532.

Garofalo, C. A., Camillo, E., Augusto, S. C., Vieira de Jesus, B. M., Serrano, J. C. (1998) Nest structure and communal nesting in Euglossa (Glossura) annectans Dressler (Hymenoptera, Apidae, Euglossini). Rev. Bras. Zool. 15, 589-596.

González, V. H., Ospina, M., Palacios, E., Trujillo, E. (2007) Nesting habitats and rates of cell parasitism in some bee species of the genera Ancyloscelis, Centris and Euglossa (Hymenoptera: Apidae) from Colombia. Bol. Mus. Ent. Univ. Valle, 8 (2), 23-29.

Michener, C. D. (1969) Comparative social behavior of bees. Annu. Rev. Entomol. 14, 299-342.

Nemésio, A., Rasmussen, C. (2011) Nomenclatural issues in the orchid bees (Hymenoptera: Apidae: Euglossina) and an updated catalogue. Zootaxa, $3006,1-42$.

Otero, J. T., Ulloa-Chacón, P., Silverstone-Sopkin, P., Giray, T. (2008) Group nesting and individual variation in behavior and physiology in the orchid bee Euglossa nigropilosa Moure (Hymenoptera, Apidae). Insect. Soc., 55, 320-328.

Pinheiro J., Bates D., DebRoy S., Sarkar D., R Core Team. (2016). nlme: Linear and Nonlinear Mixed Effects Models. R package version 3.1-128. http://CRAN. Rproject.org/package $=$ nlme

R Development Core Team (2008) R: A language and environment for statistical computing. R Foundation 
for Statistical Computing, Vienna, Austria. http://www.Rproject.org

Ramírez, S., Dressler, R.L., Ospina, M. (2002) Abejas euglosinas (Hymenoptera: Apidae) de la Región Neotropical: Listado de especies con notas sobre su biología. Biota Colomb. , 3, 7-118.

Ramírez, S.R., Eltz, T., Fujiwara, M.K., Gerlach, G., Goldman-Huertas, B., Tsutsui, N.D., Pierce, N.E. (2011) Asynchronous diversification in a specialized plant-pollinator mutualism. Science, 333, 1742-1746.

Rasmussen, C., Sánchez, E., Skov, C. (2015) Description of a nest of Euglossa heterosticta from Peru, with taxonomic notes (Hymenoptera: Apidae). J Melittol, 55, $1-8$.

Riveros, A. J., Hernández, E. J., Wcislo, W. T. (2009) Nesting biology of Euglossa dodsoni Moure (Hymenoptera: Euglossinae). J Kansas Entomol Soc, 82, 210-214.

Roubik, D. W., Hanson, P. E. (2004) Orchid Bees of Tropical America. Biology and Field Guide. Instituto Nacional de Biodiversidad (INBio), Heredia, Costa Rica.
Soucy, S. L., Giray, T., Roubik, D. W. (2003) Solitary and group nesting in the orchid bee Euglossa hyacinthina (Hymenoptera, Apidae). Insect Soc, 50, 248-255.

Venables, W. N., Ripley, B. D. (2002) Modern Applied Statistics with S. Fourth Edition. Springer, New York.

Wcislo, D.O., Vargas, G., Ihle, K.E., Wcislo, W.T. (2012) Nest construction behavior by the orchid bee Euglossa hyacinthina. J Hymenopt Res, 29, 15-20.

Weissenhofer, A., Huber, W. (2008) The climate of the Esquinas rainforest, in: Weissenhofer, A., Huber, W., Mayer, V., Pamperl, S., Weber, A., and Aubrecht, G. (Eds.), Natural and cultural history of the Golfo Dulce region, Costa Rica. Stapfia 88. Kataloge der Oberösterreichischen Landesmuseen 80, Freistadt, Austria, pp. 59-62.

Young, A. M. (1986) Presence of an orchid bee (Euglossa sp.) nest and an ant (Crematogaster limata palans) nest in a cacao pod (Theobroma cacao) (Hymenoptera: Apidae, Formicidae, resp.). Entomol News, 97, $156-162$. 